\title{
TINGKAT PENGETAHUAN MAHASISWA KEPERAWATAN TENTANG KODE ETIK PROFESI DAN CARING
}

\author{
Selvyyanny Tedjomuljo ${ }^{1 *}$, Efy Afifah ${ }^{2}$ \\ 1. Program Studi Sarjana Fakultas Ilmu Keperawatan Universitas Indonesia, Depok 16424, Indonesia \\ 2. Fakultas Ilmu Keperawatan Universitas Indonesia, Depok 16424, Indonesia \\ *E-mail: selvyyanny.tedjomuljo@gmail.com
}

\begin{abstract}
Abstrak
Kode etik dan caring harus diketahui oleh mahasiswa keperawatan karena kedua hal tersebut merupakan dasar dari profesi keperawatan. Penelitian ini bertujuan untuk mengetahui gambaran tingkat pengetahuan tentang kode etik keperawatan dan caring pada mahasiswa keperawatan. Jenis penelitian ini adalah deskriptif dengan pendekatan cross sectional pada 226 mahasiswa keperawatan melalui teknik simple random sampling. Hasil penelitian menunjukkan bahwa mahasiswa keperawatan memiliki tingkat pengetahuan yang baik (92\%) mengenai kode etik secara umum dan cukup $(47,3 \%)$ mengenai caring. Institusi pendidikan keperawatan diharapkan dapat memberikan edukasi dan memotivasi mahasiswa untuk mempraktikkan pengetahuan kode etik dan caring yang telah diberikan dalam kehidupan sehari-hari.
\end{abstract}

Kata kunci: caring, kode etik keperawatan, mahasiswa keperawatan, tingkat pengetahuan

\section{Abstract}

Level of Knowledge Nursing Students about Code of Ethics Profession and Caring. Nursing students have to know about code of ethics and caring because both of them are fundamental on nursing profession. This study used to know a representation of the level of knowledge of the nursing profession's code of ethics and caring among nursing students in Universitas Indonesia. This study used decriptive with cross sectional approach among 226 nursing students University of Indonesia by using simple random sampling methods. The results showed that nursing student in Universitas Indonesia (92\%) has a good level of knowledge of the nursing profession's code of ethics and (47,3\%) respondents has a fair level of knowledge of caring in the nursing profession. It was recommended for nursing faculty to give education and motivate students to practice the knowledge of the nursing profession's code of ethics and caring in daily activities.

Keywords: caring, code of ethics level of knowledge, nursing faculty, nursing students

\section{Pendahuluan}

Keperawatan digambarkan sebagai profesi yang bekerja dengan penuh kasih dan caring (Scott, Matthews, \& Kirwan, 2014). Namun, masih cukup banyak jumlah perawat yang belum kompeten dan bertanggung jawab dalam memberikan asuhan keperawatan. Pendidikan keperawatan memberikan kesempatan untuk meningkatkan pengetahuan seseorang mengenai isu-isu etis dan cara mengambil keputusan, serta mendapat bimbingan dalam praktik menjadi seorang perawat (Numminen, Arend \& Kipli, 2009).
Penelitian Adib-Hajbaghery dan Dianati (2005) menunjukkan bahwa sebanyak $45 \%$ mahasiswa keperawatan kurang memiliki kepribadian sesuai profesi keperawatan. Brubaker (2005) menunjukkan bahwa caring mahasiswa keperawatan di Illinois State University masih dinilai rendah dan belum berkembang. Hasil studi pendahuluan penelitian ini menemukan bahwa sebanyak $60 \%$ menjawab keperawatan bukan merupakan pilihan pertama dan keinginan menjadi perawat bukanlah merupakan keinginan yang muncul dalam hatinya. Kurangnya kepribadian untuk menjadi seorang perawat dapat berdampak terhadap perilaku mahasiswa. 
Peneliti masih melihat beberapa pelanggaran yang tidak sesuai dengan kode etik dan caring dilakukan oleh mahasiswa, seperti datang terlambat, kurang disiplin dalam mengumpulkan tugas, dan masih sering menggunakan pakaian yang tidak dianjurkan. Milanti (2007) mendapatkan bahwa perbandingan sikap $\mathrm{ca}$ ring dan non caring mahasiswa yaitu 3:2, yang menandakan bahwa perbedaan hanya terpaut satu angka, sehingga mahasiswa yang masih memiliki sikap non caring juga tidak sedikit jumlahnya.

Penelitian terkait tindakan perawat yang belum sesuai dengan kode etik dan caring dalam ranah keperawatan telah dilakukan. Namun, penelitian tingkat pengetahuan mengenai kode etik sebagai pedoman dan kerangka kerja saat melakukan praktik sesuai standar praktik organisasi profesi nasional dan caring pada mahasiswa keperawatan masih jarang ditemukan. Dengan demikian, studi untuk menggambarkan tingkat pengetahuan mengenai kode etik dan caring pada mahasiswa keperawatan penting untuk dilakukan.

\section{Metode}

Penelitian ini menggunakan desain deskriptif dengan pendekatan cross-sectional. Teknik sampling yang digunakan adalah simple random sampling, yaitu peneliti memilih secara acak responden penelitian. Kuesioner yang disebar terdiri dari 3 bagian, yaitu A untuk data demografi, B untuk mengukur tingkat pengetahuan kode etik keperawatan, dan $\mathrm{C}$ untuk mengukur tingkat pengetahuan caring pada profesi keperawatan.

\section{Hasil}

Mayoritas responden pada penelitian ini berusia 20,27-20,55 tahun dan perempuan $(n=$ $214,94,7 \%$ ). Sementara, jumlah responden di tiap angkatan hampir sama.

Tabel 1 menunjukkan karakteristik responden berdasarkan jenis kelamin dan angkatan.
Mayoritas responden memiliki tingkat pengetahuan yang baik mengenai kode etik keperawatan secara umum. Namun, dalam 7 sub variabel kode etik keperawatan, didapatkan hasil bahwa 70,4\% responden memiliki tingkat pengetahuan yang kurang terhadap sejarah kode etik keperawatan dan 97,8\% responden memiliki tingkat pengetahuan cukup terhadap definisi dan fungsi kode etik.

Tabel 1. Karakteristik Responden Berdasarkan Jenis Kelamin dan Angkatan

\begin{tabular}{ccc}
\hline Variabel & Frekuensi (n) & Persentase (\%) \\
\hline Jenis kelamin & & \\
Laki-laki & 12 & 5,3 \\
Perempuan & 214 & 94,7 \\
& & \\
Angkatan & & \\
2011 & 74 & 32,75 \\
2012 & 74 & 32,75 \\
2013 & 78 & 34,5 \\
\hline
\end{tabular}

Tabel 2. Pengetahuan tentang Kode Etik Keperawatan Responden

\begin{tabular}{cccc}
\hline Variabel & Kategori & $\begin{array}{c}\text { Frekuensi } \\
(\mathbf{n})\end{array}$ & $\begin{array}{c}\text { Persentase } \\
(\boldsymbol{\%})\end{array}$ \\
\hline Pengetahuan & Baik & 208 & 92 \\
kode etik & Cukup & 17 & 7,5 \\
keperawatan & Kurang & 1 & 0,5 \\
secara umum & & & \\
\hline
\end{tabular}

Tabel 3. Pengetahuan tentang Caring Profesi Keperawatan Responden

\begin{tabular}{llll}
\hline \multicolumn{1}{c}{ Variabel } & Kategori & \multicolumn{1}{c}{ n } & \% \\
\hline Pengetahuan & Baik & 96 & 42,5 \\
caring & Cukup & 107 & 47,3 \\
& Kurang & 23 & 10,2 \\
\hline
\end{tabular}

Tabel 2 menunjukkan tingkat pengetahuan responden mengenai kode etik keperawatan. Mayoritas responden yang memiliki tingkat pengetahuan baik mengenai kode etik keperawatan, yaitu angkatan $2013(\mathrm{n}=72)$. Sebagian besar mahasiswa $(n=192 ; 85 \%)$ memiliki tingkat pengetahuan kurang mengenai sistem nilai kemanusiaan dan altruistis. Sebagian besar mahasiswa $(n=146$ 64,6\%) juga memiliki tingkat pengetahuan kurang mengenai penggunaan metode sistematis dalam memecahkan 
masalah. Sebanyak 172 orang $(76,1 \%)$ memiliki tingkat pengetahuan kurang mengenai proses belajar mengajar interpersonal.

Tabel 3 menunjukkan tingkat pengetahuan responden mengenai caring profesi keperawatan. Mayoritas responden memiliki tingkat pengetahuan cukup mengenai caring secara umum.

Tabel 4. Pengetahuan tentang Kode Etik Keperawatan Responden Berdasarkan Angkatan

\begin{tabular}{cccc}
\hline \multirow{2}{*}{ Angkatan } & \multicolumn{3}{c}{$\begin{array}{c}\text { Pengetahuan tentang kode etik } \\
\text { keperawatan }\end{array}$} \\
\cline { 2 - 4 } & Baik & Cukup & Kurang \\
\hline 2011 & 68 & 6 & 0 \\
2012 & 68 & 6 & 0 \\
2013 & 72 & 5 & 1 \\
\hline
\end{tabular}

Tabel 5. Pengetahuan tentang Caring Profesi Keperawatan Responden Berdasarkan Angkatan

\begin{tabular}{cccc}
\hline \multirow{2}{*}{ Angkatan } & \multicolumn{3}{c}{$\begin{array}{c}\text { Pengetahuan tentang caring pada } \\
\text { profesi keperawatan }\end{array}$} \\
\cline { 2 - 4 } & Baik & Cukup & Kurang \\
\hline 2011 & 36 & 31 & 7 \\
2012 & 36 & 33 & 5 \\
2013 & 24 & 43 & 11 \\
\hline
\end{tabular}

Mayoritas responden yang memiliki tingkat pengetahuan baik mengenai caring adalah angkatan 2011 dan $2012(\mathrm{n}=36)$. Tabel 4 dan 5 menunjukkan tingkat pengetahuan mengenai kode etik dan caring berdasarkan angkatan.

\section{Pembahasan}

Usia responden berada pada rentang 17-23 tahun (remaja akhir dan dewasa awal). Usia ini mampu berpikir kritis dan memecahkan masalah meningkat karena pengalaman pendidikan baik secara formal dan informal, pengalaman hidup, dan pekerjaan (Potter, Perry, Stockert, \& Hall, 2013). Selanjutnya dijelaskan juga bahwa dalam tahap ini kepedulian dan rasa empati kepada orang lain, serta minat terhadap isu-isu sosial meningkat. Usia seseorang merupakan salah satu variabel yang memengaruhi perkembangan kemampuan kognitif.
Responden dalam penelitian ini didominasi oleh perempuan $(n=214)$. Hasil ini serupa dengan penelitian Indrawati (2012) yang mendapatkan hasil bahwa 93,1\% respondennya mayoritas adalah perempuan. Fakta ini selaras dengan pernyataan Riverby tahun 1987 mengenai perawat yang dianggap sebagai pekerjaan perempuan karena perempuan memiliki peran biologis untuk mengasuh dan merawat anak dalam keluarga (Radsma, 1994). Keperawatan dipandang sebagai profesi yang didominasi oleh perempuan, sehingga hasil yang terlihat adalah persentase jumlah perawat laki-laki sangat rendah (Cuadra \& Famadico, 2013).

Lamanya seseorang menjadi mahasiswa dapat menjadi acuan untuk melihat mata kuliah yang telah diselesaikan. Peneliti tidak memilih mahasiswa S1 reguler angkatan 2014 karena berdasarkan hasil wawancara yang dilakukan pada 5 mahasiswa didapatkan hasil bahwa mahasiswa baru menerima mata kuliah Konsep Dasar Keperawatan pada semester kedua, sehingga pengetahuan mengenai kode etik keperawatan belum dapat diukur.

Hasil penelitian ini mendapatkan bahwa tingkat pengetahuan mengenai kode etik secara umum adalah baik (92\%). Hasil tersebut hampir sejalan dengan penelitian sebelumnya yang diujikan kepada mahasiswa keperawatan di Turki dengan hasil $85,7 \%$ cukup memahami kode etik keperawatan ICN dan 83,8\% memahami masalah etik dan dilema yang sering terjadi pada praktik keperawatan (Dinc \& Gorgulu, 2002). Hal ini menandakan bahwa pengetahuan tentang kode etik keperawatan dan isinya secara umum sudah dipahami oleh mahasiswa keperawatan.

Tingkat pengetahuan mahasiswa 2013 mengenai kode etik keperawatan lebih tinggi dibandingkan angkatan 2011 dan 2012. Kemungkinan hal ini terjadi karena angkatan 2013 masih baru melewati mata ajar KDK 1 dan 2 sehingga pengetahuan tentang kode etik keperawatan masih dapat diingat lebih banyak. Berbeda 
halnya, dengan mahasiswa angkatan 2012 dan 2011 yang beberapa di antaranya mengungkapkan telah lupa tentang kode etik keperawatan karena banyaknya materi keperawatan yang telah didapatkan.

Perawat harus siap terlibat aktif dalam membuat keputusan etis yang dapat memengaruhi peran mereka dan perawatan terhadap klien (Chaloner, 2007). Oleh karena itu, mata ajar keperawatan mengenai etika keperawatan memberikan mahasiswa kesempatan untuk mempelajari etika, masalah etik, dan dilema etik yang terdapat dalam dunia keperawatan.

Walaupun tingkat pengetahuan responden sudah baik mengenai kode etik keperawatan, namun dalam beberapa sub variabel kode etik keperawatan pengetahuan mahasiswa perlu ditingkatkan. Dalam analisis, didapatkan bahwa tingkat pengetahuan mahasiswa kurang ( $\mathrm{n}=$ $159,70,4 \%$ ) mengenai sejarah kode etik keperawatan. Hal ini terjadi karena responden tidak terlalu mengetahui secara tepat evolusi dari kode etik keperawatan. Kode etik keperawatan pertama kali mulai dikembangkan oleh Listra Gretter pada tahun 1893 yang dikenal dengan Ikrar Nightingale yang kemudian ditetapkan sebagai kode etik oleh The Nurses' Associated Alumnae of The United States and Canada (Hook \& White, 2003; Fowler, 2010).

Selain itu, tingkat pengetahuan mahasiswa dalam sub variabel definisi dan fungsi kode etik keperawatan dinilai cukup baik. Hasil ini berbeda dengan penelitian sebelumnya yang menyatakan bahwa $89,7 \%$ mahasiswa di Hacettepe University School of Nursing, Turki mengetahui tentang definisi dari konsep dan prinsip dalam etika (Dinc \& Gorgulu, 2002).

Tingkat pengetahuan yang baik tentang perawat dan teman sejawat sebanyak 144 orang $(63,7 \%)$. Penelitian ini sejalan dengan penelitian Brown yang menggunakan 231 perawat sebagai responden dengan hasil yang didapatkan, yaitu sikap positif perawat saat berkolaborasi dengan sesama tenaga kesehatan
(Brown, Lindell, Dolansky, \& Garber, 2015). Dengan demikian, responden telah menyadari bahwa dokter merupakan mitra kerja perawat. Perawat memiliki prosedur dan kesepakatan profesional yang diatur dalam kode etik dan hukum untuk mengevaluasi setiap tugas dan tanggung jawab yang dilakukan, sehingga tujuan pelayanan kesehatan bagi klien dapat tercapai secara menyeluruh (Minnesota Nurses Association, 2007).

Tingkat pengetahuan mahasiswa terhadap isi kode etik mengenai perawat dan klien; perawat dan praktik; perawat dan masyarakat; dan perawat dan profesi memiliki tingkat pengetahuan yang baik. Hasil ini membuktikan bahwa mahasiswa telah memahami bahwa isi kode etik keperawatan di dalamnya menjelaskan tentang tanggung jawab perawat kepada klien, masyarakat, praktik, dan profesi (Weis \& Schank, 2009).

Tingkat pengetahuan mahasiswa mengenai caring, yaitu cukup baik $(n=107,47,3 \%)$. Hasil ini menggambarkan bahwa tingkat pengetahuan mahasiswa tentang caring masih belum mencapai kriteria baik. Bila dibandingkan dengan hasil penelitian Milanti (2007) yang menunjukkan 97 mahasiswa $(n=161)$ memiliki sikap caring, sementara 64 mahasiswa memiliki sikap non caring, maka hasil ini dapat menggambarkan bahwa tingkat pengetahuan caring dapat memengaruhi sikap caring seseorang (Koswara, 2002). Pembelajaran mengenai caring saat duduk di bangku perkuliahan, memiliki tujuan ke depan, yaitu agar mahasiswa dapat menunjukkan sikap caring terhadap tuntutan situasi praktik sebenarnya (Beck, 2001).

Tingkat pengetahuan caring angkatan 2011 dan 2012 memiliki tingkat pengetahuan yang baik dibandingkan angkatan 2013. Hal ini dikarenakan mahasiswa angkatan 2011 dan 2012 telah memasuki praktik klinik, yaitu melakukan praktik langsung dengan klien, baik di rumah sakit, panti, maupun komunitas. Hal ini sesuai dengan pendapat Blum (2010 
dikutip dalam Rosecrans, 2014) yang menemukan bahwa dua dari tiga perilaku caring berubah ketika mahasiswa menghabiskan waktu bersama klien dan tidak merasa lelah untuk melakukan itu. Pendapat tersebut bukan berarti mahasiswa angkatan 2013 masih belum mengetahui caring. Hal ini terjadi karena mahasiswa keperawatan yang masih baru (dalam hal ini mahasiswa 2013) masih terfokus pada perkuliahan yang harus diselesaikan dengan baik (Rosecrans, 2014).

Sebanyak $85 \%$ responden memiliki tingkat pengetahuan yang kurang mengenai sub variabel sistem nilai kemanusiaan dan altruistis. Dalam hal ini, mahasiswa belum memahami makna altruis, yang terlihat dalam menjawab bahwa toleransi merupakan sikap mendahulukan kepentingan orang lain.

Sejalan dengan hasil tersebut, Rognstad (2007) mengemukakan bahwa terjadi perubahan nilainilai profesional dalam mahasiswa keperawatan pada beberapa tahun terakhir terlebih dari dimensi altruisme. Penelitian lain menyebutkan bahwa dalam waktu 20 tahun terakhir ini, terjadi penurunan dari dimensi altruisme pada mahasiswa keperawatan saat ini (Johnson, Haigh, \& Yates-Bolton, 2007). Hal ini sulit diidentifikasi karena altruisme merefleksikan sistem nilai diri seseorang. Selain itu, faktor yang memengaruhi nilai altruistik seseorang, yaitu motivasi yang mendukung pilihan profesi dan orientasi nilai pribadi profesional keperawatan (Mecugni, Albinelli, Pellegrin, \& Finotto, 2015).

Sub variabel berikutnya yang menggambarkan tingkat pengetahuan mahasiswa kurang adalah penggunaan metode sistematis dalam memecahkan masalah. Responden masih banyak yang belum mengerti mengenai tindakan yang dapat langsung dilakukan oleh perawat tanpa kolaborasi dengan teman sejawat lain. Keperawatan profesional melakukan pemecahan masalah secara ilmiah dan sistematik sesuai dengan metodologi dan proses keperawatan (Gauna, 1998). Penelitian Paldanius \& Maatta
(2011) mengatakan bahwa keputusan klien harus dipertimbangkan ketika membuat keputusan dalam keperawatan. Namun demikian, perawat merupakan wali klien yang telah mendapat pengetahuan mengenai asuhan keperawatan. Mahasiswa keperawatan seharusnya bukan hanya paham mengenai caring, namun dapat menggunakan ilmu pengetahuan keperawatan dan kemampuan teknik pemberian asuhan perawatan dalam menyelesaikan permasalahan klien (Karaoz, 2005).

Tingkat pengetahuan mahasiswa mengenai proses belajar mengajar interpersonal didapatkan masih kurang. Responden banyak menjawab salah mengenai peran perawat sebagai health educator. Meskipun peran perawat umumnya membantu memenuhi kebutuhan klien, namun bukan berarti klien secara terus menerus setiap harinya dibantu oleh perawat.

Tingkat pengetahuan mahasiswa dalam sub variabel kepekaan pada diri sendiri digambarkan cukup. Hal ini sependapat dengan Rognstad (2004, dalam Solvoll \& Heggen, 2010) yang menemukan bahwa tingginya rasa untuk mementingkan diri sendiri dan kurangnya rasa empati pada mahasiswa keperawatan saat ini.

Sub variabel curahan perasaan didapatkan bahwa responden memiliki tingkat pengetahuan yang cukup. Penelitian kualitatif yang dilakukan Adamski, Parsons, dan Hooper (2009) terdapat mahasiswa yang berpendapat bahwa caring adalah tentang komunikasi dan kepercayaan diri. Melalui pengajaran dan proses sosialisasi dalam pendidikan keperawatan, kemampuan mahasiswa untuk berkomunikasi dengan baik dapat semakin meningkat.

Mahasiswa memahami bahwa caring terbentuk melalui proses sosialisasi selama kehidupan dan juga pendidikan, bukan diturunkan secara genetik. Hal ini diperkuat dengan pernyataan Lebold and Douglas (1998, dalam Hsieh, 2003) yang menyatakan bahwa walaupun caring tidak diajarkan, mahasiswa kepera- 
watan masih dapat mempelajarinya melalui praktik ilmiah, bacaan, tulisan jurnal dan artikel, berpikir, dan berdialog. Dalam sub variabel harapan akan kepercayaan, mahasiswa memahami tindakan yang harus dilakukan seorang perawat, yaitu mendorong dan memotivasi klien dan orang lain yang sedang dalam keadaan putus asa sehingga meyakini bahwa masih ada harapan untuk menyelesaikan setiap permasalahan.

Mahasiswa juga memahami bahwa hubungan saling percaya merupakan hal yang harus dilakukan perawat dan klien. Hal ini sejalan dengan penelitian kualitatif Rhodes, Morris, dan Lazenby (2011) yang mengemukakan bahwa sebagian besar mahasiswa mengatakan bahwa hubungan saling percaya antara perawat dan klien merupakan bagian penting dalam caring. Blum (2010, dalam Rosecrans, 2014) menyatakan bahwa hubungan saling percaya dapat terjadi saat perawat menghabiskan banyak waktu dengan klien.

Mahasiswa memahami dan mengetahui bahwa menyediakan lingkungan yang kondusif bagi klien dapat mempengaruhi status kesehatannya. Lingkungan eksternal meliputi faktor fisik dan sosial, seperti rumah, udara, kualitas air, dan asupan gizi, sedangkan lingkungan internal merupakan lingkungan yang disediakan perawat untuk klien, berupa lingkungan spiritual dan kesejahteraan mental.

Mahasiswa keperawatan memiliki tingkat pengetahuan yang baik dalam memotivasi klien untuk tetap percaya bahwa kekuatan spiritual dapat menjadi koping untuk menghadapi masalah kesehatannya dan Tuhan dapat memberikan keajaiban dalam kehidupannya. Berbeda dengan hasil penelitian lainnya (Bennett \& Thompson, 2015) yang mengatakan secara konsisten menunjukkan bahwa kemampuan perawat untuk berhubungan dengan perawatan spiritual lemah karena persiapan peran sebagai perawat yang kurang saat menempuh pendidikan keperawatan.

\section{Kesimpulan}

Gambaran tingkat pengetahuan mahasiswa keperawatan mengenai kode etik dinilai baik. Namun, masih terdapat beberapa aspek sub variabel yang ada dalam kode etik belum diketahui secara baik oleh mahasiswa, seperti sejarah, definisi, dan fungsi kode etik keperawatan.

Pengetahuan mahasiswa masih belum mencapai kriteria baik untuk caring. Dalam aspek caring, mahasiswa belum sepenuhnya memahami peran caring perawat dalam 10 faktor karatif Watson, seperti sistem nilai kemanusiaan dan atruistis, menggunakan metode sistematis untuk memecahkan masalah, proses belajar mengajar interpesonal, kepekaan terhadap diri sendiri dan orang lain, serta mencurahkan perasaan positif maupun negatif.

Praktik di wahana praktik berperan membantu mahasiswa untuk mengaplikasikan pengetahuan yang telah dimiliki. Institusi pendidikan mendapatkan tantangan untuk memberikan pengajaran bukan hanya lewat teori, namun dapat memberikan contoh agar pengetahuan mahasiswa semakin kuat untuk melakukan sikap caring dalam kehidupan sehari-hari $(\mathrm{HH}$, TN, AR).

\section{Referensi}

Adamski, M., Parsons, V., \& Hooper, C. (2009). Internalizing the concept of caring: An examination of student perceptions when nurses share their stories. Nursing Education Perspectives, 30 (6), 358-361. Diperoleh dari https://www.ncbi.nlm.nih.gov/pubmed/199999 36

Beck, C.T. (March, 2001). Caring within nursing education: A metasynthesis. Journal of Nursing Education, Vol. 40 No. 3, 101-109. Diperoleh dari https://www.ncbi.nlm.nih.gov/p ubmed/11302537

Bennett, V., \& Thompson, M.L. (2015). Teaching spirituality to student nurses. Journal of 
Nursing Education and Practice, 5 (2), 26-33. Diperoleh dari http://www.sciedu.ca/journal/i ndex.php/jnep/article/download/5105/3523

Brown, S.S., Lindell, D.F., Dolansky, M.A., \& Garber, J.S. (2015). Nurses' professional values and attitudes toward collaboration with physicians. Nursing Ethics, 22 (2), 205-216. doi: 10.1177/0969733014533233

Brubaker, C.L. (2005). An instrument to measure ethical caring in clinical encounters between student nurses and patients (Dissertations \& Theses Global). Illinois State University. Diperoleh dari http://search.proquest.com/doc view/

Chaloner, C. (2007). An introduction to ethics in nursing. Nursing Standard, 21 (32), 42-46.

Cuadra, D.S., \& Famadico, L.F. (2013). Male nursing students' emotional intelligence, caring behavior and resilience. International Journal of Arts \& Sciences, 6 (3), 243-260. Diperoleh dari http://universitypublications.net /ijas/0603/html/ijas-cont-0603.pdf

Dinc, L. \& Gorgulu, R.S. (2002). Teaching ethics in nursing. Nursing Ethics, 9 (3), 259-268. doi: $10.1177 / 096973300200900305$

Fowler, M.D.M. (2010). Guide to the code of ethics for nurses: Interpretation and application. Silver Spring, Maryland: American Nurses Association (ANA).

Gauna, M.C. (1998). An exploration of the carative beliefs and behaviors of female emergency room nurses: a study of caring in theory and practice (Dissertations \& Theses Global). Diperoleh dari http://search.proquest.com/doc view/

Adib-Hajbaghery, M., \& Dianati, M. (2005). Undergraduate nursing students' compatibility with the nursing profession. BMC Medical Education, 5 (25). doi:10.1186/1472-6920-525

Hook, K.G., \& White, G.B. (2003). Code of Ethics for Nurses with Interpretive Statements: An independent study module. Washington, DC: ANA. Diperoleh dari http:// www.nursingwo rld.org/mods/mod580/cecdefull.htm.
Hsieh, J.L. (2003). An Educational Strategy to Enhance Caring in Nursing Students in an Associate Degree Program. International Journal for Human Caring, 7 (1), 27-33.

Johnson, M., Haigh C., \& Yates-Bolton N. (2007). Valuing of altruism and honesty in nursing students: A two-decade replication study. Journal of Advanced Nursing, 57 (4), 366-374. doi:10.1111/j.1365-2648.2007.04119.x

Karaoz, S. (2005). Turkish nursing students' perception of caring. Nurse Education Today, 25, 31-40. doi: 10.1016/j.nedt.2004.09.010

Koswara, D. (2002). Hubungan antara pengetahuan caring dengan sikap caring perawat pelaksana di ruang rawat inap RSUD Tasikmalaya tahun 2002 (Tesis, tidak dipublikasikan). Program Magister Fakultas Ilmu Keperawatan Universitas Indonesia, Depok, Jawa Barat.

Mecugni, D., Albinelli, P., Pellegrin, J., \& Finotto, S. (2015). The Italian validation of the SalfordScott nursing values questionnaire. Nursing Ethics, 22 (2), 248-260. doi: 10.1177/0969 733014533236

Milanti, A. (2007). Sikap caring mahasiswa FIK UI (Tugas Akhir, tidak dipublikasikan). Fakultas Ilmu Keperawatan Universitas Indonesia, Depok, Jawa Barat.

Minnesota Nurses Association. (2007, JanuaryFebruari). Code of ethics for nurses: The standard of caring. Minnesota Nursing Accent, 8-9. Diperoleh dari http://mnnurses.org/wpcontent/uploads/2015/11/history-posters.pdf

Numminen, O., van der Arend, A., Kilpi, H.L. (2009) Nurse educators' and nursing students' perspectives on teaching codes of ethics. Nursing Ethic, 16 (1), 69-82. doi: 10.1177/ 0969733008097991.

Paldanius, A., \& Maatta, K. (2011). What are students' views of (loving) caring in nursing education in Finland? International Journal of Caring Sciences, 4 (2), 81-89. Diperoleh dari http://www.internationaljournalofcaringscience s.org/docs/Vol4_Issue2_04_Paldanius.pdf 
Potter, P.A., Perry, A.G, Stockert, P., \& Hall, A. (2013). Fundamental of nursing (8th Ed.). St. Louis: Elsevier Mosby.

Radsma, J. (1994). Caring and nursing: A dilemma. Journal of Advanced Nursing, 20, 444-449.

Rhodes, M.K., Morris, A.H., \& Lazenby, R.B. (2011). Nursing at its best: Competent and caring. The Online Journal of Issues in Nursing, 16 (2), 10. doi: 10.1111/j.13652834.2007.00655.x

Rognstad, M.K., \& Aasland, O. (2007). Change in career aspirations and job values from study time to working life. Journal of Nursing Management, 15, 424-432.

Rosecrans, K.K. (2014). Caring behaviors of nursing students (Dissertations \& Theses
Global). Diperoleh dari http://search.proquest .com/docview/

Scott, P.A., Matthews, A., \& Kirwan, M. (2014). What is nursing in the 21 st century and what does the 21st century health system require of nursing? Nursing Philosophy, 15, 23-34. doi: 10.1111/nup.12032

Solvoll, B.A., \& Heggen, K.M. (2010). Teaching and learning care-Exploring nursing students' clinical practice. Nurse Education Today, 20, 73-77.

Weis, D., \& Schank, M.J. (2009). Development and psychometric evaluation of the nurses professional values scale-revised. Journal of Nursing Measurement, 17 (3), 221-231. doi: http://dx.doi.org/10.1891/1061-3749.17.3.221 